解 説

スラリキャストした金属・セラミックのガス雾囲気反応焼結による多孔質セラミック

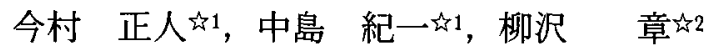

野口裕之汭, 中川 威雄访3

新東工業侏東京研究所, 个338 浦和市西堀4-6-10.

22 日本工業大学機械工学科, $\overline{\mathbf{T}} 345$ 埼玉県南埼玉郡宮代町学園台4-1.

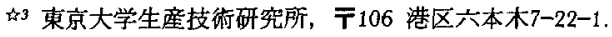

\title{
Reaction Sintering of Porous Ceramic from Slurry Cast Metal-ceramic Green Compact in Gas Atmosphere
}

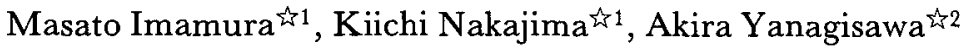 \\ Hiroyuki Noguchi ${ }^{23}$ and Takeo Nakagawa ${ }^{\text {r } 3}$ \\ 1) 1 Tokyo Research Center, Sintokogio Ltd., Nishibori, Urawa 338. \\ tr2 Dept. Mech. Eng., Nippon Inst. of Tech., Gakuendai Miyashiro, Saitama 345. \\ 45 Institute of Industrial Science, Tokyo University, Roppongi Minato, Tokyo 106.
}

Received January 13, 1993

\begin{abstract}
Porous ceramics mere made by means of sintering the compacts manufactured by slurry casted mixtures of the powders of metal and ceramics in the atmospheres of various gases. According to this method, some near-net shaped porous ceramics were acquried owing to the balance of the size change between the expansion in the reaction process of the metal powders and the atomosphere gas and the shirinkage in the sintering process. Some conceptional descriptions about this methode are made in this paper.
\end{abstract}

\section{1 楮言}

スラリキャストした金属・セラミック混合粉末 多孔質成形体をガス雾囲気内で焼結することによ り，雺囲気ガスと金属との反俯焼結（セラミック 化）過程での膨張とその後の焼結収縮がバランス して寸法変化が小さい焼結体が製造できる。著者 らはこの方法を用いて通常の金型成形で用いる大 がかりな設備を用いずに，鉄ームライト混合粉末 成形体を製造し，さらに大気中で酸化焼結するこ とにより，金型寸法とほほ等しい寸法を示す，酸 化鉄一ムライト複合焼結体の製造が可能であるこ

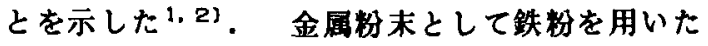
場合には固相反応であるが, アルミなど
較的低蛅点の金属を用いた場合には液相反応とな り反応挙動は異なる．これらの自己反応焼結の)挙 動についての基本的概念のまとめを報告する.

\section{2 ニヤネットシェイプ成形のための考え方}

一般に粉末成形体は焼結で収縮するため, 寸法 変化を小さくする為になんらかの方法で殿張因子 を焼結工程に導入する必要がある. 通常の方法の 場合にはこれは期待できないので，取縮分を見远 んで大きめに作る必要がある（伸尺の使用）. 反 応焼結の埸合には付加反応で成形体を勮張させる 事が可能で，金属系の焼結材では一般的に行なわ れているが，これをセラミックの焼結に利用する. 
具体的には金属のガス化合物であるセラミック そのものを㸮末成形・焼結して製品を作るのでは なく，セラミックを構成する金属を㸮末成形し， 焼結時に成形体外から導入したガスと反応焼結さ せてセラミック制品を作る方法で，付加反応によ り膨張をもたらす事で寸法変化を小さくできる( Fig. 1 参照) .
これを連鎖的に進行させれば良いのでそれほど大 きな振動は必要としない，スラリ粘性におよほす これらの効果はFig. 2 に示すように比較的大き いので, 基本的には掁幅 $1 \mathrm{~mm}$ 以下で振動数 $100 \mathrm{~Hz}$ 以下で充分な流動性を与えることができる．とこ ろが実際の加振状態では追従時間や溶媒添加量に 対する流動性の変化が大きいために，コンクリー

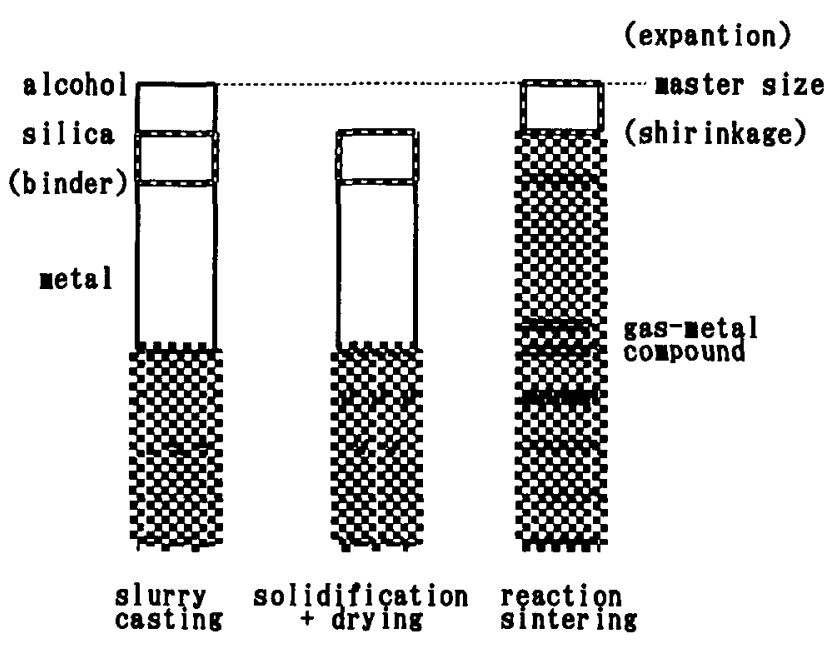

Fig. 1 Schenatic illustration of slurry-casting and self reaction sintering.

\section{3 グリーン体の成形}

\section{1 振動スラリキャスティング}

成形法として無加圧成形法の一つである振動ス ラリキャスティングを用いる.

通常の圧縮成形では製造可能な成形体の大きさ が使用するプレスの能力に依存し，しかも金型成 形の場合には成形抵抗により成形体の均一性も問 題となる。

スラリキャスティングでは溶媒を使用して粉末 を流動化させるため，成形にあたって加圧力を必 要とせずに衯末を型内に流入できる．流動性を与 えるための適切な溶媒量は粉末の粒度分布に応じ て変化する3-5)，そのため，使用する物末粒間を 埋めるだけの最低限の溶媒を添加して湿潤したあ とて，チクソトロピーを生かして振動により流動 化する（低エネルギ無加圧成形）。今回は，使用 している粉末の平均粒径が約数 $101 \mathrm{k}$ と大きく溶媒 との分離傾向が大きいために振動方式を使用する。

作用させる振動は振幅と振動数が問題になる。 これは掦載重量に依存する。さらにスラリに関し ては加振時間によりその性状は大きく变化する。 基本的にはスラリ中の粉末粒子 1 個を移動させ，

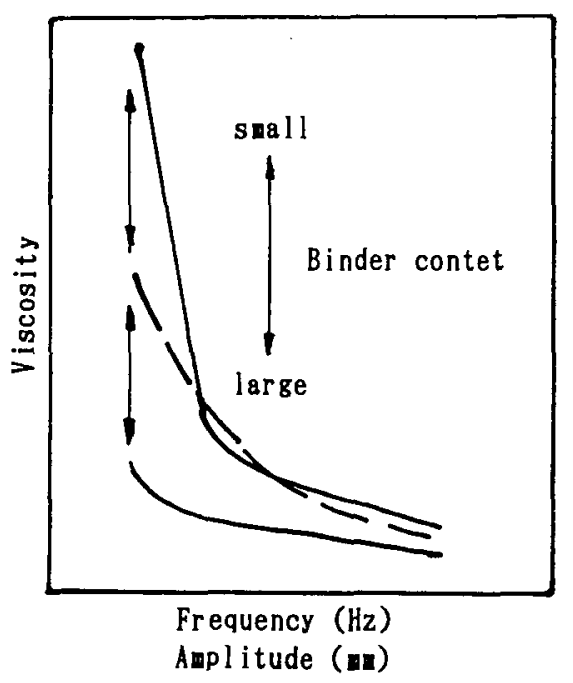

Fig.2 Effect of frequency, ampl itude and binder content on the viscosity.

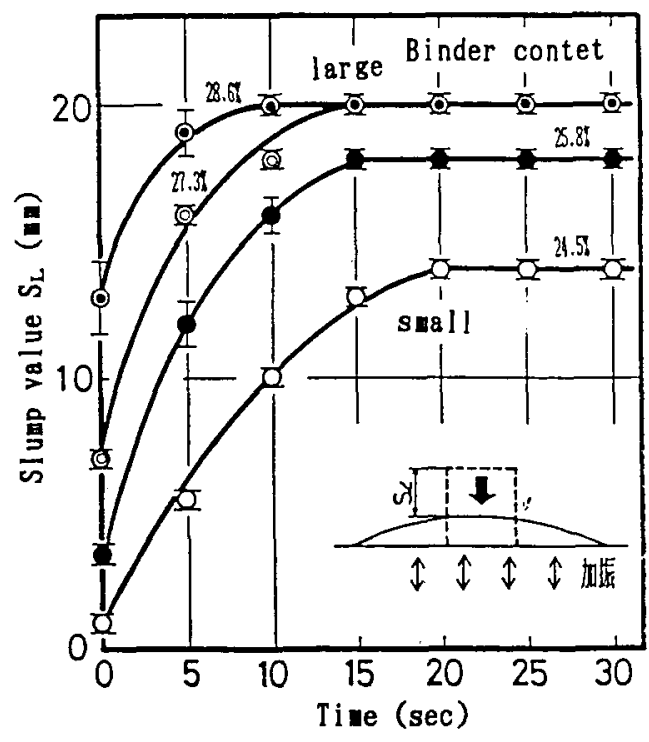

Fig. 3 Variation of slump value with tiae.

ト工学て使われるモルタルの流動性を示すスラン プ值の変化が Fig. 37に示されるように著しく変 化する。 


\section{2 自硬性せシミック}

しかむ溶媒としてそれ自体が固化特性をむつ自 硬性無機バインダ (加水分解エチルシリケート) を用いているため, 成形ムラを生じる可能性が小 さく，此較的均一な成形体を簡便に得られるため

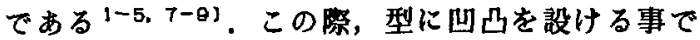
微細菭写も可能となる. 加えて，石音型の使用の ようにスリップ中の溶媒液の抽出により固化せず に，バインダの硬化後に溶媒を乾燥除去できるこ とも特徽である。この慗，乾焻クラック防止のた めに強化用㵶維（ファイバ）を利用する事もある घ)。た，脱泡不良の改善や過剩バインダの抜き 取りが必要であれば低加圧力成形（流動成形）す る事もあるの。

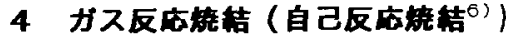

反応焼結は基本となる物質を混合したグリーン 成形体マトリクスでの元素間の反応である．今回 は反応用ガスをグリーン体の系外の霛囲気から導 入し，反応させる方式である．成形体は多孔質で あり，連通気孔を通じて表面だけでなく内部まで ガスの進入が進む101ので，比較的容易に反応焼結 が進行し，成形体内の金属粉のセラミック化が進 み既に存在するセラミック粒子間を拡げると共に 基地強度が生じる. 類似反応に C V と C V I の 関保がある。

\section{5 基地梂張のための基本アイデフ（考虑点）}

反応椟結を進める際に種々の問題が生じたので， 対策を陆じて処理する。

問題点(1)：ガスとの反応以前にマトリクス材料の 焼結が進む

対 策：流動層あるい仗侇雑物を入れる

意 図：マトリクス材を分離・分散

問題点(2)：セラミック粉末粒径（金属粉末粒径に 対して)

対 策：小さくする（従来法：凝集防止） 大きくする(石垣棈造)

意 図：金属粉の分離 $\rightarrow$ セミック㸮間の拡大の促進 これらの関保をまとめて Fig. $4^{111}$ に示した。 問題点(3)：見掛けの膨張量が小さい

対 策：バインダ量を少なくする

意 図：ガス反応膨張を積極的に利用するた め, 雾囲気湿度の調整により充填密 度を上げる事で，相対膨張量を大き くする。

\section{6 ガス反応の実例}

セラミック特に，酸素あるいは登菜化合物の場 合には金属粉末成形体のガス反応焼結が可能であ る.

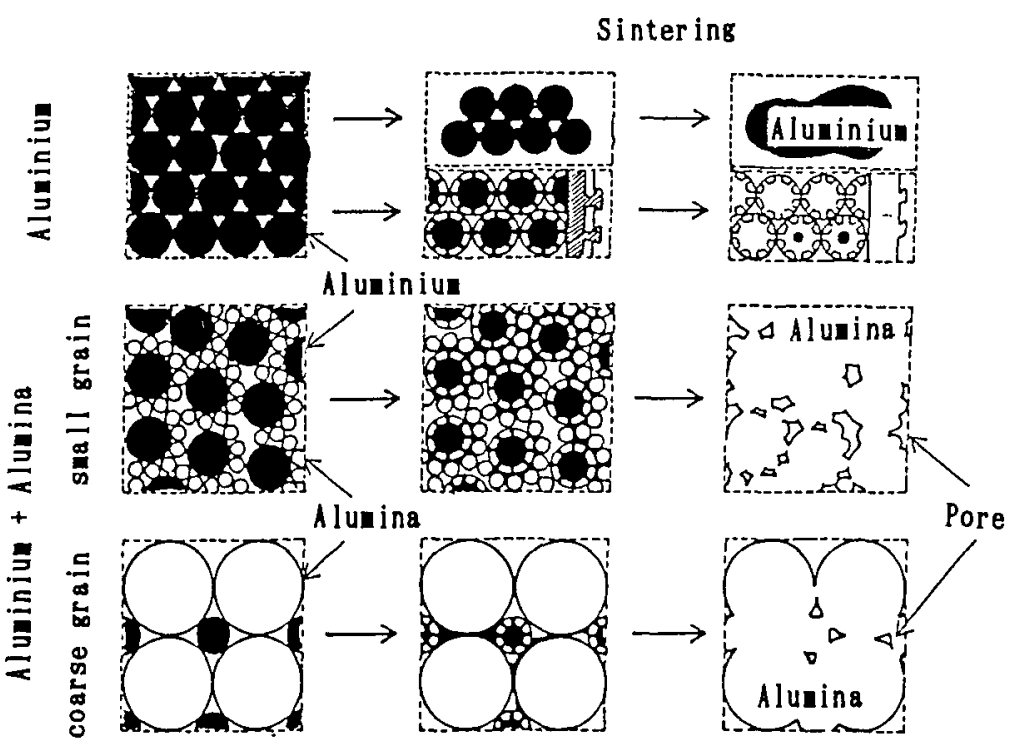

Fig.4 Schenatic illustration of react ion-sintering between aluriniur and oxyzen in storosphere. 
6.1 酸化 (大気) 等囲気

○ F e (介在相 : ムライト)

Fig. 5 に示すように反応風の成長は時間に対し て一次式 ${ }^{12)}$ で現せ，充分なガスの供給がなされる 表面反応律則である。しかも，反応焼結温度へ迅 速に昇温するするほうが成長速度が大きい事から， 酸化物の核生成頻度が高く反応が進みやすい事を 示唆している。

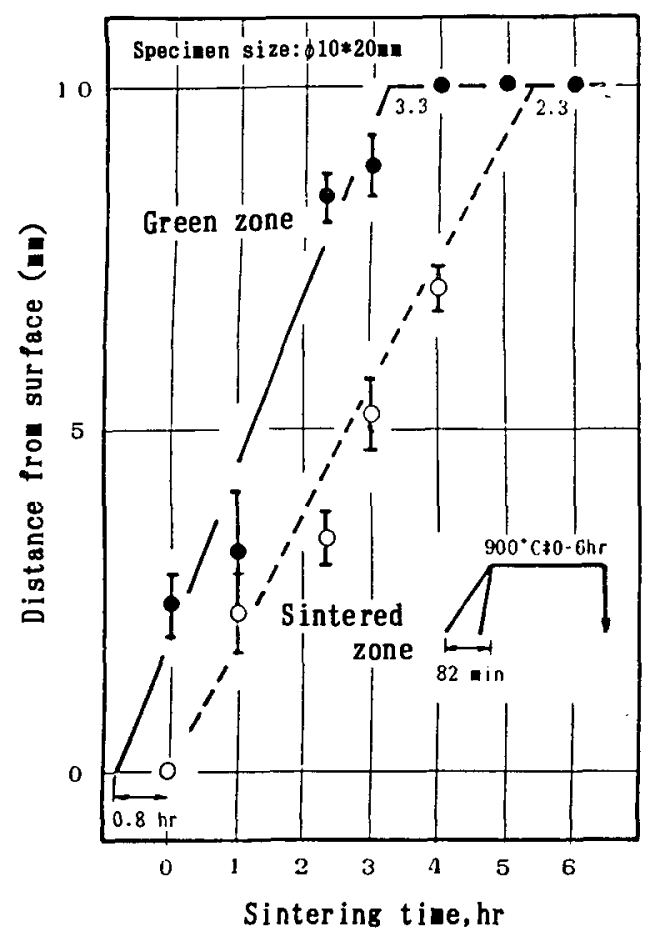

Fig. 5 Effect of heating rate on the sintering of iron-nullite.

\section{（）A 1（介在相：アルミナ）}

通常の圧縮成形体では金属粉の涌出が起きるた め，20\%13）以上金国物を入れる事ができなかった が，無加圧成形多孔体ではそれ以上も可能である。 基本的に強度は反応で生じたセラミック囸に比例 するので，金属相は多い万が望ましいが，多過ぎ ても反応が遅れるので，適切な配合量が存在する， 勿論，焼結温度の効果も大きく，比較的高い(1573 K）方が望ましい，原料アルミ粉に含まれるガス量 からもともと約数 $\mathrm{nm}$ のアルミナ皮膜に覆われてい るものの，これを微細に破壊して溶蛆アルミが流 失し，寄囲気ガスと反応して，酸化アルミとなり， アルミナ自体の焼結温度に比較して500〜 700Kも低 い温度て反応し，ほほ連続的にセラミック化して いくもの之考察している ${ }^{3-5)}$.
○ A 1 （介在相：ムライト）

セラミック粉としてアルミナ・シリカ系のム ライト粉を用いた場合にはシリカよりもアルミナ の方が安定であるため，

$3(3 \mathrm{Al} 203 \cdot 2 \mathrm{Si} 02)+8 \mathrm{Al}=9+4 \mathrm{Al} 203+6 \mathrm{Si}$

となり, シリコンがアルミと直換する(テルミット 反応 $)^{31}$.

\section{2 窒化宗囲気}

（） S i （介在相：窒化珪素）

$\mathrm{F}$ e の場合とほほ同じ条件7).

（） A 1 (介在相：アルミナ)

反応熱が大きいので, 連鎖的に急速に反応が 進み，表面の気孔を塞ぐ，その場合には焼結温度 を下げているも゙。

\section{7 结言}

スラリキャスティングによる自硬多れ質グリー ン成形体のガス霝囲気下ての直接ガス反応焼結に より, 強度のある寸法変化の小さい複雑形状の多 孔質焼結体が製造できる。

\section{文}

1）今村正人,柳沢章,野口裕之,中川威雄: 粉体及 び粉末治金, 37(1990)521。

2）今村正人, 宮本和彦, 媿杰, 中川威雄: 物体及び 粉末冶金, 37(1990)1199.

3）今村正人, 中島紀一,柳沢章,中川威雄: 粉体及 び粉末治金, 40(揭載予定).

4）今村正人, 中島紀一, 本吉道喜, 柳沢章, 中川威 雄:粉体及び枌末治金, 40（揭載予定）

5）今村正人, 中島紀一,市川義崇, 柳沢章, 中川威 雄: 粉体及び粉末治金, 40(揭載予定)

6）塩野率司,高㞾,古村展之,西田俊彦,西川友三: 旭硝子財団研究報告, 58(1991)69.

7) 堤信久，今村正人, 石毛俊郎: 錆物, 61(1989) 411 .

8）今村正人，柳沢章，野口裕之,中川威雄: 物体及 び粉末冶金, 35(1988)625.

9）今村正人，柳沢章,野口裕之,中川威雄: 粉体及 び粉末冶金, 35(1988)629.

10) I. Ljungberg, P.U. Gummeson:Precision Metal Molding, 17(1959) 30 .

11）本吉道喜,市川義崇, 柳沢章, 今村正人, 中島紀 一,中川威雄:日本MRS第4回年次講演大会(1992) IP16.

12）笛木和雄:電気化学, 37(1969)312

13）松尾重友,米谷勝利, 松木義明: 嚜協, 73(1965) 82 . 